\title{
Causal relationship between acute pancreatitis and methylprednisolone pulse therapy for fulminant autoimmune hepatitis: a case report and review of literature
}

\author{
Daisuke Nango ${ }^{1,3^{*}}$, Hiroki Nakashima', Yukifumi Hirose ${ }^{1}$, Masaaki Shiina ${ }^{2}$ and Hirotoshi Echizen ${ }^{3}$
}

\begin{abstract}
Background: A causal relationship between acute pancreatitis and administration of glucocorticoids remains a matter of debate, since most of the reported cases were diagnosed with systemic vascular diseases (including systemic lupus erythematosus and polyarteritis nodosa) that may be responsible for the pancreatitis.

Case presentation: We report a case of a 51-year-old woman who developed acute pancreatitis after receiving methylprednisolone pulse therapy for the treatment of fulminant autoimmune hepatitis (AlH). She was admitted to our hospital because of overt jaundice and back pain. Since her liver dysfunction deteriorated progressively, a liver biopsy was performed and a diagnosis of AlH was established. She was given intravenous methylprednisolone pulse therapy at $1000 \mathrm{mg} /$ day for 3 days, and oral prednisolone at $40 \mathrm{mg} /$ day thereafter. While her liver function improved rapidly, she started complaining of mild back pain and serum amylase and lipase levels were elevated from 5 days after the initiation of steroid therapy. A CT scan revealed mildly edematous changes around the pancreas, leading to a diagnosis of acute pancreatitis. After tapering off prednisolone, back pain disappeared, and elevated serum amylase was normalized without exacerbation of $\mathrm{AlH}$. A systematic literature review identified 8 cases of acute pancreatitis developing after administration of corticosteroid pulse therapy with a median latent period of 5 days.

Conclusions: The present case and reports in the literature suggest that steroid pulse therapy may cause acute pancreatitis in patients having no signs of systemic vasculitis.
\end{abstract}

Keywords: Steroid pulse therapy, Autoimmune hepatitis, Acute pancreatitis, Short-term tapering

\section{Background}

Acute pancreatitis has been reported to be a rare, albeit severe, adverse reaction associated with administration of corticosteroids [1]. However, the causal relationship between corticosteroid treatment and pancreatitis remains controversial, since many reported cases were either diagnosed with systemic vasculitis [such as systemic lupus erythematosus (SLE)] that may be complicated

\footnotetext{
* Correspondence: d.nango@gmail.com

'Departments of Pharmacy, Shin-Yurigaoka General Hospital, 255

Furusawa-tsuko, Asao-ku, Kawasaki, Kanagawa 215-0026, Japan

${ }^{3}$ Department of Pharmacotherapy, Meiji Pharmaceutical University, 2-522-1

Noshio, Kiyose, Tokyo 204-8588, Japan

Full list of author information is available at the end of the article
}

with pancreatitis [2] or given medications known to cause pancreatitis (such as anticancer drugs) [3]. Here, we report a 51-year-old woman who developed acute pancreatitis after receiving steroid pulse therapy for the treatment of fulminant autoimmune hepatitis (AIH), which is not known to cause pancreatitis. We also discuss the causal relationship in the light of previous reports retrieved by a systematic literature survey.

\section{Case presentation}

A well-nourished 51-year-old woman visited our hospital because of fatigue, overt jaundice, and back pain on March 2016 (day 1). In the present article, each of the 
important clinical events occurred during the clinical course of the patient was described by "days" after the patient's first visit to our hospital. The patient was afebrile and had no arthralgia. Physical examination revealed icteric sclera but no signs of facial erythema. No lymphadenopathy was detected. Chest and abdominal findings were noncontributory. No bruise was observed on the abdomen. She was taking no medications. Laboratory data obtained at the first visit are shown in Table 1. Serum amylase and calcium levels were normal. The titers of antinuclear antibody and anti-mitochondrial antibody were within normal limits. IgM antibodies for hepatitis viruses $\mathrm{Bc}, \mathrm{A}$ and $\mathrm{E}$ were negative. Her medical history included cholecystectomy due to gall bladder polyps and cholelithiasis one year earlier, uterine myoma left untreated, and undefined complaints tentatively diagnosed as autonomic imbalance. She did not smoke or drink alcohol. When she revisited for follow-up first days later, she was admitted emergently because of severely deteriorated liver function (day 5). Serum concentrations of total bilirubin, serum

Table 1 Laboratory data of the patient at the first visit

\begin{tabular}{|c|c|c|}
\hline $\begin{array}{l}\text { Peripheral blood } \\
\text { counts }\end{array}$ & Blood chemistry & Serological tests \\
\hline WBC $3700(/ \mu \mathrm{L})$ & TP 7.6 (g/dL) & HBs antigen (-) \\
\hline $\operatorname{RBC} 451\left(10^{4} / \mu \mathrm{L}\right)$ & Alb 4.1 (g/dL) & HCV antibody (-) \\
\hline Hb 13.7 (g/dL) & T-Bil 5.54 (mg/dL) & $\begin{array}{l}\text { ANA } \times 20 \text { (normal } \\
\text { range }<\times 20 \text { ) }\end{array}$ \\
\hline Ht 40.7 (\%) & D-Bil 4.14 (mg/dL) & $\operatorname{lgG} 2010$ (mg/dL) \\
\hline MCV 90 (fl) & AST 577 (U/L) & IgA 283 (mg/dL) \\
\hline MCH 30.4 (pg) & ALT 1055 (U/L) & $\operatorname{lgM} 215$ (mg/dL) \\
\hline MCHC 33.7 (g/dL) & ALP 503 (U/L) & $\begin{array}{l}\text { AMA-M2 } 1.6 \\
(\text { normal range }<7 \text { ) }\end{array}$ \\
\hline Platelet $8.8\left(10^{4} / \mu \mathrm{L}\right)$ & LDH 338 (U/L) & $\operatorname{lgM}-\mathrm{HBC}(-)$ \\
\hline \multirow[t]{8}{*}{ CRP 0.17 (mg/dL) } & y-GTP 241 (U/L) & $\operatorname{IgM}-\mathrm{HA}(-)$ \\
\hline & Amylase $82(\mathrm{U} / \mathrm{L})$ & $\operatorname{lgA}-\mathrm{HE}(-)$ \\
\hline & BUN 10.8 (mg/dL) & \\
\hline & $\begin{array}{l}\text { Creatinine } 0.42 \\
(\mathrm{mg} / \mathrm{dL})\end{array}$ & \\
\hline & $\mathrm{Na} 140$ (mEq/L) & \\
\hline & K 4.1 (mEq/L) & \\
\hline & $\mathrm{Cl} 106$ (mEq/L) & \\
\hline & Calcium 8.7 (mg/dL) & \\
\hline
\end{tabular}

Abbreviations: $W B C$ white blood cell, $R B C$ red blood cell, $H b$ hemoglobin, $\mathrm{Ht}$ hematocrit, $M C V$ mean cell volume, $M C H$ mean corpuscular hemoglobin, $M C H C$ mean cell hemoglobin concentration, $A l b$ serum albumin, $T$-Bil serum total bilirubin, $D$-Bil serum direct bilirubin, $A S T$ serum aspartate aminotransferase, $A L T$ serum alanine aminotransferase, $A L P$ serum alkaline phosphatase, $L D H$ serum lactate dehydrogenase, $\gamma$-GTP serum $\gamma$-glutamyl transpeptidase, $B U N$ blood urea nitrogen, $H B$ s hepatitis $B$ surface, $H C V$ hepatitis $C$ virus, $A N A$ antinuclear antibody, $\lg G$ immunoglobulin $\mathrm{G}, \lg A$ immunoglobulin a, $\lg M$ immunoglobulin $\mathrm{M}, A M A$ anti-mitochondrial antibody, $H B C$ hepatitis $\mathrm{B}$ core, $H A$ hepatitis a, $H E$ hepatitis $E$ alanine aminotransferase, serum aspartate aminotransferase, and serum alkaline phosphatase were $17.48 \mathrm{mg} / \mathrm{dL}$, $1099 \mathrm{U} / \mathrm{L}, 708 \mathrm{U} / \mathrm{L}$, and $460 \mathrm{U} / \mathrm{L}$, respectively. Percent prothrombin time (PT\%) also decreased to $77 \%$, indicating ongoing acute hepatic decompensation. A CT scan revealed no signs of bile duct stenosis, cholelithiasis, and neoplasms in the hepato-pancreatic region.

Figure 1 shows the time courses of clinical events, laboratory data and medications given to the patient during her hospitalization. On the 12th day, a percutaneous fine-needle aspiration biopsy of the liver was performed. Histopathological examination revealed minimal to mild portal inflammation, mild interface hepatitis, and serious intralobular focal necrosis with plasmocytic infiltration. Inflammation was also seen around biliary canaliculi. According to the current diagnostic criteria of $\mathrm{AIH}[4,5]$, the patient had an AIH score of 12 points. AIH scores of 10 to 15 points are consistent with a probable diagnosis, and scores $\geq 16$ points with a definite diagnosis.

Since we judged that development of liver failure was imminent, we began corticosteroid pulse therapy with $1000 \mathrm{mg} /$ day of methylprednisolone for 3 days under a diagnosis of fulminant AIH (day 17). After completion of the pulse therapy, oral prednisolone was started at $40 \mathrm{mg} /$ day. Famotidine ( $40 \mathrm{mg} /$ day) was also given to prevent gastric mucosal injury. Five days after the commencement of steroid pulse therapy (day 21), the patient developed mild back pain. And then, serum amylase and lipase levels abruptly increased to $575 \mathrm{U} / \mathrm{L}$ and $582 \mathrm{U} / \mathrm{L}$, respectively. Since a plain CT scan revealed mild swelling around the pancreatic head (Fig. 2), a diagnosis of acute pancreatitis was made (day 23). Assuming that the development of acute pancreatitis was associated with administration of corticosteroids, we started tapering off prednisolone (day 24). Since we were concerned that an abrupt withdrawal of prednisolone might have exacerbated $\mathrm{AIH}$, we underwent an accelerated tapering off of the prednisolone doses according to the schedule shown in Fig. 1. Specifically, we reduced 5 to $10 \mathrm{mg} /$ day every 1 to 3 days from $40 \mathrm{mg} /$ day to $10 \mathrm{mg} /$ day. We monitored serum liver enzymes frequently over the following 10 days and detected no signs of reactivation of AIH. After an uneventful clinical course, the patient was discharged from hospital with a maintenance dose of prednisolone $(10 \mathrm{mg} /$ day $)$ on the 33rd day after admission.

\section{Literature search}

We searched the MEDLINE ${ }^{\circ}$ database and the medical journal database of Japan Medical Abstracts Society for case reports describing the development of acute pancreatitis after administration of corticosteroid pulse therapy. For MEDLINE ${ }^{\circ}$ search the following combinations of $\mathrm{MeSH}^{\bullet}$ vocabulary terms were used: "adrenal cortex hormones"[MeSH Terms] OR "steroids"[MeSH Terms]) 


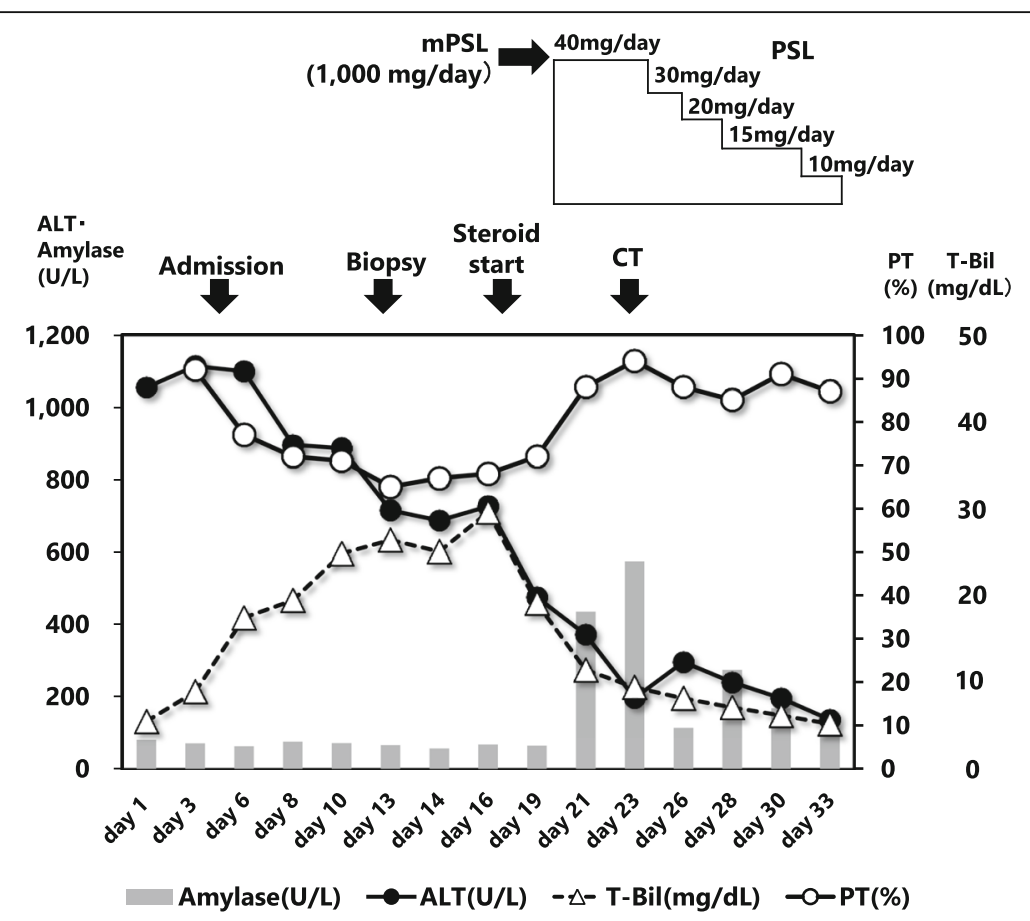

Fig. 1 The clinical course of the present patient, with laboratory data and details of methylprednisolone pulse therapy and subsequent oral prednisolone. Each of the important clinical events occurred during the clinical course of the patient was described by "days" after the patient's first visit to our hospital. Abbreviations: $\mathrm{CT}=$ computed tomography, T-Bil = serum total bilirubin, ALT = serum alanine aminotransferase, Amy = serum amylase, $\mathrm{mPSL}=$ methylprednisolone, $\mathrm{PSL}=$ prednisolone, $\mathrm{PT}=$ prothrombin time

and "pancreatitis"[MeSH Terms] AND Case Reports [ptyp] and "humans"[MeSH Terms] and (English [lang] OR Japanese [lang]). For the search of Japan Medical Abstracts Society, the following combinations of search terms were used: (( (pancreatitis / TH) AND (adrenal cortex hormone / $\mathrm{TH})$ ) and $(\mathrm{PT}=$ case report)) and ("pulse therapy (drug treatment)" / TH). We retrieved eight relevant cases of acute pancreatitis (2 from MEDLINE $^{\oplus}$ and 6 from the database of Japan Medical

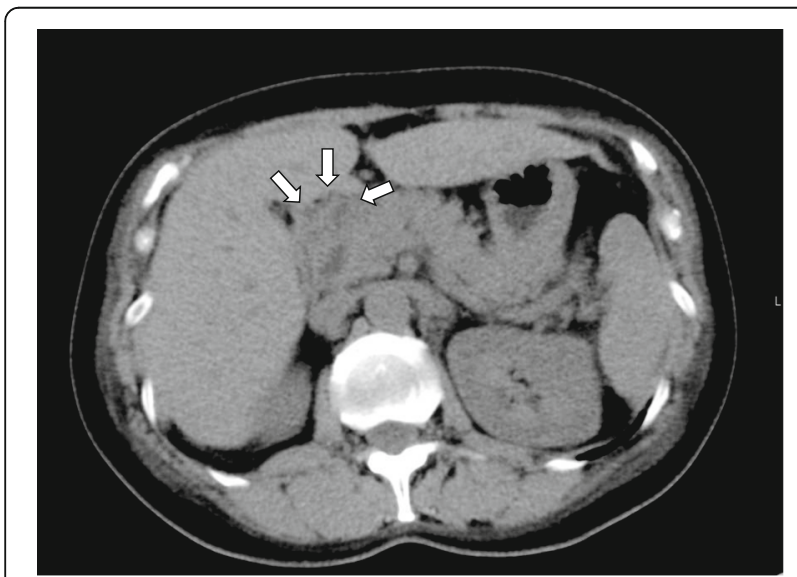

Fig. 2 The CT image taken on Day 23 showing edematous changes around the head of pancreas (denoted by arrows). The finding is compatible with a diagnosis of acute pancreatitis
Abstracts Society). The synopses of the cases including the present case are summarized in Table 2.

\section{Discussion}

We believe that the present case report provides another line of evidence supporting the causality between the administration of corticosteroid pulse therapy and the development of acute pancreatitis. In the present case, the diagnosis of acute pancreatitis was definite, since it was made not only based on clinical symptoms and biochemical data but was confirmed by CT images. In contrast, the causal relationship between the administration of corticosteroid and the development of acute pancreatitis can only be inferred by exclusion of other possible causes. Acute pancreatitis has been reported to be associated with diverse clinical conditions such as cholelithiasis, heavy alcohol consumption, hypertriglyceridemia, hypercalcemia, pancreatic divisum, systemic vasculitis such as SLE, polyarteritis nodosa, trauma, viral infection (such as mumps) and drug use. While our patient had a medical history of cholelithiasis and gallbladder polyps, she underwent cholecystectomy one year earlier and the possibility of recurrent cholelithiasis or malignancy at the hepato-pancreatic region was excluded by the findings obtained from repeated CT scan examinations. In addition, she had never consumed alcohol or smoked before developing acute pancreatitis. While she took 
Table 2 Previously reported cases and the present case of acute pancreatitis developing after administration of corticosteroid pulse

\begin{tabular}{|c|c|c|c|c|c|c|c|c|}
\hline $\begin{array}{l}\text { References } \\
\text { (year) }\end{array}$ & $\begin{array}{l}\text { Age }(y r) / \\
\text { Sex }\end{array}$ & Primary Disease & $\begin{array}{l}\text { Cardinal } \\
\text { symptoms }\end{array}$ & Doses of steroids & $\begin{array}{l}\text { Peak serum } \\
\text { amylase }(U / L)\end{array}$ & $\begin{array}{l}\text { Period for } \\
\text { treatment at } \\
\text { the episode } \\
\text { (day) }\end{array}$ & Concomitant drugs & Outcome \\
\hline $\begin{array}{l}\text { The present } \\
\text { case }\end{array}$ & $51 / F$ & $\begin{array}{l}\text { Autoimmune } \\
\text { hepatitis }\end{array}$ & Back pain & $\begin{array}{l}\mathrm{mPSL} 1000 \mathrm{mg} / \mathrm{day} \text {, } \\
\text { then PSL } 60 \mathrm{mg} / \text { day }\end{array}$ & 436 & 5 & Famotidine & Survived \\
\hline $\begin{array}{l}\text { Nishimoto } \\
\text { et al. [20] } \\
\text { (2014) }\end{array}$ & $18 / \mathrm{M}$ & $\begin{array}{l}\text { Acute monocytic } \\
\text { leukemia }\end{array}$ & $\begin{array}{l}\text { Abdominal } \\
\text { pain }\end{array}$ & mPSL 1000 mg/day & 451 & 5 & $\begin{array}{l}\text { Cytarabine, imipenem/ } \\
\text { cilastatin, piperacillin/ } \\
\text { tazobactam, vancomycin, } \\
\text { meropenem }\end{array}$ & Survived \\
\hline $\begin{array}{l}\text { Jimi et al. [21] } \\
\text { (2013) }\end{array}$ & $70 / F$ & $\begin{array}{l}\text { ANCA-associated } \\
\text { nephritis }\end{array}$ & $\begin{array}{l}\text { Epigastric } \\
\text { pain }\end{array}$ & $\begin{array}{l}\mathrm{mPSL} 1000 \mathrm{mg} / \mathrm{day} \text {, } \\
\text { then PSL } 35 \mathrm{mg} / \text { day }\end{array}$ & 2400 & 5 & NA & Survived \\
\hline $\begin{array}{l}\text { Suganuma } \\
\text { et al. [22] } \\
\text { (2012) }\end{array}$ & $2 / \mathrm{M}$ & Kawasaki Disease & $\begin{array}{l}\text { Abdominal } \\
\text { pain }\end{array}$ & $\begin{array}{l}\mathrm{mPSL} 15 \mathrm{mg} / \mathrm{kg} / \text { day } \\
\text { (BW, } 13.5 \mathrm{~kg} \text { ), then } \\
\text { PSL } 10 \mathrm{mg} / \text { day for } \\
3 \text { days, then } 5 \\
\mathrm{mg} / \text { day for } 3 \text { days }\end{array}$ & 2075 & 7 & Flurbiprofen & Survived \\
\hline $\begin{array}{l}\text { Iwata et al. } \\
\text { [23] (2010) }\end{array}$ & 9/F & $\begin{array}{l}\text { MPO-ANCA-associated } \\
\text { glomerulonephritis }\end{array}$ & $\begin{array}{l}\text { Abdominal } \\
\text { pain }\end{array}$ & $\begin{array}{l}\mathrm{mPSL} 30 \mathrm{mg} / \mathrm{kg} / \text { day } \\
\text { (BW, } 22.8 \mathrm{~kg} \text { ), then } \\
\text { PSL } 25 \mathrm{mg} / \text { day }\end{array}$ & 159 & 5 & Mizoribine & Survived \\
\hline $\begin{array}{l}\text { Tsuruoka } \\
\text { et al. [24] } \\
\text { (2008) }\end{array}$ & $72 / \mathrm{F}$ & $\begin{array}{l}\text { ANCA-associated } \\
\text { glomerulonephritis }\end{array}$ & $\begin{array}{l}\text { Back pain, } \\
\text { epigastric } \\
\text { pain }\end{array}$ & $\begin{array}{l}\text { mPSL } 500 \text { mg/day, } \\
\text { then PSL } 20 \text { mg/day }\end{array}$ & 306 & 20 & NA & Died \\
\hline $\begin{array}{l}\text { Nakayama et al. } \\
\text { [25] (2004) }\end{array}$ & $60 / F$ & $\begin{array}{l}\text { MPO-ANCA-associated } \\
\text { glomerulonephritis }\end{array}$ & $\begin{array}{l}\text { Epigastric } \\
\text { pain }\end{array}$ & $\begin{array}{l}\mathrm{mPSL} 500 \mathrm{mg} / \text { day, } \\
\text { then PSL } 40 \mathrm{mg} / \text { day }\end{array}$ & 1519 & 5 & Cyclophosphamide & Survived \\
\hline $\begin{array}{l}\text { Kotaka et al. } \\
\text { [26] (2002) }\end{array}$ & $67 / F$ & Myasthenia gravis & $\begin{array}{l}\text { Back pain, } \\
\text { vomiting }\end{array}$ & mPSL 1 g/day & 3593 & 2 & NA & Survived \\
\hline $\begin{array}{l}\text { Yoshizawa et al. } \\
\text { [7] (1999) }\end{array}$ & $80 / F$ & Bullous pemphigoid & $\begin{array}{l}\text { Nausea, } \\
\text { epigastric } \\
\text { pain }\end{array}$ & $\begin{array}{l}\text { mPSL } 1 \text { g/day, then } \\
\text { PSL } 30 \text { mg/day }\end{array}$ & 1195 & 4 & $\begin{array}{l}\text { Alfacalcidol, } \\
\text { calcium lactate, } \\
\text { propentofylline, } \\
\text { vinpocetine, } \\
\text { omeprazole }\end{array}$ & Survived \\
\hline
\end{tabular}

NA no information was available in original report, MPSL methylprednisolone, PSL prednisolone, BW body weight

famotidine $40 \mathrm{mg} /$ day during the corticosteroid pulse therapy, a previous nested case-control study performed in UK reported no cases of idiopathic pancreatitis among current users of famotidine [6]. Previous studies suggested a dose-dependent risk of developing pancreatitis during corticosteroid treatment, with thresholds of $25 \mathrm{mg} /$ day for prednisolone [7]. In this context, patients receiving corticosteroid pulse therapy may have a higher risk of developing pancreatitis than those receiving lower doses of corticosteroids. In addition, a previous population based-cohort study suggested that acute pancreatitis developed between 4 and 14 days after the initiation of corticosteroids [8]. Our literature survey showed that $87.5 \%$ of the cases (7 out of 8 cases) developed pancreatitis within 14 days after the initiation of corticosteroids. In our case, pancreatitis developed 7 days after the initiation of steroid therapy. Collectively, we consider that the development of acute pancreatitis in the present case was most likely due to the methylprednisolone pulse therapy.

Many cases of acute pancreatitis in patients receiving corticosteroids combined with other drugs have been reported [9-14]. However, the causality between the administration of corticosteroids and development of acute pancreatitis in these cases remains inconclusive, since the patients treated with corticosteroids were diagnosed with autoimmune diseases manifesting systemic vasculitis (such as SLE and polyarthritis nodosa), which are sometimes complicated with pancreatitis irrespective of the administration of corticosteroids. Patients with antineutrophil cytoplasmic antibody (ANCA)-associated glomerulonephritis have been reported to be complicated with acute pancreatitis [15-17]. In addition, patients affected by autoimmune diseases receive corticosteroids as well as immunosuppressive drugs (such as azathioprine) that are associated with high risk of developing pancreatitis. Our literature survey revealed that many cases of acute pancreatitis developing after administration of corticosteroid pulse therapy were diagnosed with systemic vasculitis (such as ANCA-associated glomerulonephritis) or were given pancreatitis-inducing drugs (such as cyclophosphamide). In contrast, the present case had primary diseases that are unlikely to be associated with pancreatitis and received no drugs that may induce pancreatitis. Collectively, we considered that administration of methylprednisolone pulse therapy rather than the primary disease was responsible for the pancreatitis. Based on this clinical judgement, we withdrew prednisolone using a 
short-term tapering method. No signs of exacerbation in AIH activity were detected, probably because corticosteroids are highly effective in suppressing the disease activity of AIH. Previous studies showed that corticosteroids were effective in 36 to 100\% [18] and 92\% [19] of AIH patients.

\section{Conclusions}

The present case and some reported cases strongly suggest a causal relationship between the administration of corticosteroids and the development of acute pancreatitis.

\section{Abbreviations}

AlH: Autoimmune hepatitis; ANCA: Antineutrophil cytoplasmic antibody; SLE: Systemic lupus erythematosus

\section{Funding}

The authors received no financial support for the research, authorship, and/ or publication of the present article.

\section{Availability of data and materials}

The data used in the present case report will not be shared due to the risk of identifying an individual, although most patient's data are presented in the text.

\section{Authors' contributions}

DN and HE wrote the manuscript. HN, YH and MS helped to draft the manuscript. All authors read and approved the final manuscript.

\section{Ethics approval and informed consent}

The present case report was submitted to the ethics committee of ShinYurigaoka General Hospital for review prior to the submission to the Journal. The ethics committee waived the need for reviewing the present case report according to the current ethics quideline for the medical research for humans. Nevertheless, the committee confirmed that the present case report was written by retrospective data collection and the patient's anonymity and confidentiality are appropriately protected. Witten informed consent was obtained from the patient.

\section{Consent for publication}

A copy of the written consent is available for review by the Editor-in-Chief of this journal.

\section{Competing interests}

The authors declare that they have no competing interest.

\section{Publisher's Note}

Springer Nature remains neutral with regard to jurisdictional claims in published maps and institutional affiliations.

\section{Author details}

'Departments of Pharmacy, Shin-Yurigaoka General Hospital, 255

Furusawa-tsuko, Asao-ku, Kawasaki, Kanagawa 215-0026, Japan.

${ }^{2}$ Gastroenterology and Hepatology, Shin-Yurigaoka General Hospital, 255

Furusawa-tsuko, Asao-ku, Kawasaki, Kanagawa 215-0026, Japan. ${ }^{3}$ Department of Pharmacotherapy, Meiji Pharmaceutical University, 2-522-1 Noshio, Kiyose, Tokyo 204-8588, Japan.

Received: 20 March 2018 Accepted: 24 May 2018

Published online: 31 May 2018

\section{References}

1. Jones MR, Hall OM, Kaye AM, Kaye AD. Drug-induced acute pancreatitis: a review. Ochsner J. 2015;15:45-51.

2. Makol A, Petri M. Pancreatitis in systemic lupus erythematosus: frequency and associated factors - a review of the Hopkins lupus cohort. J Rheumatol. 2010;37:341-5

3. Blomgren KB, Sundström A, Steineck G, Genell S, Sjöstedt S, Wiholm BE. A Swedish case-control network for studies of drug-induced morbidity-acute pancreatitis. Eur J Clin Pharmacol. 2002;58:275-83.
4. Alvarez F, Berg PA, Bianchi FB, Bianchi L, Burroughs AK, Cancado EL, et al. International autoimmune hepatitis group report: review of criteria for diagnosis of autoimmune hepatitis. J Hepatol. 1999;31:929-38.

5. Onji Morikazu, Zeniya M, Yamamoto K, Tsubouchi H. Diagnosis and treatment guide for autoimmune hepatitis in Japan. Kanzo. 2013;54:723-5. (Japanese)

6. Eland IA, Alvarez $\mathrm{CH}$, Stricker BH, Rodríguez LA. The risk of acute pancreatitis associated with acid-suppressing drugs. Br J Clin Pharmacol. 2000;49:473-8.

7. Yoshizawa Y, Ogasa S, Izaki S, Kitamura K. Corticosteroid-induced pancreatitis in patients with autoimmune bullous disease: case report and prospective study. Dermatology. 1999;198:304-6.

8. Sadr-Azodi O, Mattsson F, Bexlius TS, Lindblad M, Lagergren J, Ljung R. Association of oral glucocorticoid use with an increased risk of acute pancreatitis: a population-based nested case-control study. JAMA Intern Med. 2013;173:444-9.

9. Imada M. Case of pancreatitis following cortico-steroid therapy of nephrotic syndrome. Nihon Shonika Gakkai Zasshi. 1966;70:96-102. (Japanese)

10. Okumura H, Miyahara K, Ito K, Koshimura O, Hashimoto K. Review of literature and a case report of steroid pancreatitis. Naika. 1969;23:915-20. (Japanese)

11. Hamed I, Lindeman RD, Czerwinski AW. Case report: acute pancreatitis following corticosteroid and azathioprine therapy. Am J Med Sci. 1978;276: 211-9.

12. Jain R, Ramanan SV. latrogenic pancreatitis: a fatal complication in the induction therapy for acute lymphocytic leukemia. Arch Intern Med. 1978; 138:1726.

13. Baron M, Brisson ML. Pancreatitis in systemic lupus erythematosus. Arthritis Rheum. 1982;25:1006-9.

14. Ossi E, Fiocco U, Belloni M, Ongaro G, Rubaltelli L, Ruffatti A, et al. Therapy of acute pancreatitis in systemic lupus erythematosus with plasmapheresis and corticosteroids. Clin Exp Rheumatol. 1983;1:345-7.

15. Yassin N, Büchler M, Uhl W, Scherbaum WA. Antineutrophil cytoplasmic autoantibodies (ANCA) in acute pancreatitis. Hepato-Gastroenterology. 1992; 39:533-5.

16. lida T, Amari Y, Yurugi T, Nakajima F. Myeloperoxidase antineutrophil cytoplasmic antibody (MPO-ANCA)-associated glomerulonephritis with acute pancreatitis: a case report. Nihon Jinzo Gakkai Shi. 2015;57:783-8. (Japanese)

17. lida T, Adachi T, Tabeya T, Nakagaki S, Yabana T, Goto A, et al. Rare type of pancreatitis as the first presentation of anti-neutrophil cytoplasmic antibodyrelated vasculitis. World J Gastroenterol. 2016;22:2383-90.

18. Ichai P, Duclos-Vallée JC, Guettier C, Hamida SB, Antonini T, Delvart V, et al. Usefulness of corticosteroids for the treatment of severe and fulminant forms of autoimmune hepatitis. Liver Transpl. 2007;13:996-1003.

19. Kaneko A, Tatsumi T, Yakushiij T, Hiramatsu N, Mita E, Nakanishi F, et al. Present status of steroid administration to patients with autoimmune hepatitis and factors associated with relapse. Kanzo. 2015;56:507-17. (Japanese)

20. Nishimoto M, Koh H, Bingo M, Yoshida M, Nanno S, Hayashi Y, et al. Posterior reversible encephalopathy syndrome following acute pancreatitis during chemotherapy for acute monocytic leukemia. Rinsho Ketsueki. 2014; 55:552-7. (Japanese)

21. Jimi K, Norikazu W, Asako G, Miyaoka Y, Rie S, Yuri F, et al. A case of ANCAassociated nephritis that developed acute pancreatitis after steroid pulse therapy. Jpn J Renol. 2013;55:1088. (Japanese)

22. Suganuma H, Kamata A, Niizuma T, Kinoshita K, Obinata K, Shimizu T. A case of Kawasaki disease complicated with acute pancreatitis after steroid pulse therapy. JMJ. 2012;58:344-7.

23. Iwata S, Tanahashi Y, Tuma Y, Oshima K, Manabe T, Ito K, et al. Case of MPOANCA-associated glomerulonephritis with acute pancreatitis, perforated duodenal ulcer and posterior reversible encephalopathy syndrome after steroid pulse therapy. Nihon Shoni Jinzobyo Gakkai Zasshi. 2010;23:29-34. (Japanese)

24. Tsuruoka K, Sekiya S, Yokoyama T, Koitabashi K, Shimazaki M, Sakurada T, et al. MPO-ANCA related vasculitis complicating mucinous cystadenoma of the pancreas and severe acute pancreatitis after steroid pulse therapy: a case report. Nihon Jinzo Gakkai Shi. 2008;948-53(Japanese):50.

25. Nakayama H, Yutaka O, Obayashi H, Aoike I, Sakurabayashi T, Miyazaki S, et al. A case of MPO-ANCA-associated nephritis that developed acute pancreatitis after initiation of steroid pulse therapy. Jpn J Renol. 2004; 605(Japanese):46.

26. Kotaka T, Kanzaki A, Nakamura Y, Yoshinaga J. A case of myasthenia gravis (MG) complicated with severe pancreatitis after steroid pulse therapy. J Hiroshima Med Assoc. 2002;935-6(Japanese):55. 